\title{
The Comparison of Think Talk Write and Think Pair Share Model with Realistic Mathematics Education Approach Viewed from Mathematical-Logical Intelligence
}

\author{
Himmatul Afthina, Mardiyana, Ikrar Pramudya \\ Postgraduate School of Mathematics Education, Sebelas Maret University, Jl. Ir. Sutami No. \\ 36A, Jebres, Surakarta, Jawa Tengah 57126, Indonesia \\ himmatulafthina@gmail.com
}

\begin{abstract}
The aims of this research to determine the effect of Think Talk Write (TTW) and Think Pair Share (TPS) model with Realistic Mathematics Education (RME) approach viewed from mathematical-logical intelligence. This research employed the quasi experimental research. The population of research was all students of the eight graders of junior high school in Karangamyar Regency in academic year 2016/2017. The result of this research shows that (1) TTW with RME approach gave better mathematics achievement than TPS with RME approach, (2) Students with high mathematical-logical intelligence can reach a better mathematics achievement than those with average and low, whereas students with average mathematical-logical intelligence can reach a better achievement than those with low one, (3) In TTW model with RME approach, students with high mathematical-logical intelligence can reach a better mathematics achievement than those with average and low, whereas students with average and low mathematicallogical intelligence gave same mathematics achievement, and in TPS model with RME approach students with high mathematical-logical intelligence can reach a better mathematics achievement than those with average and low, whereas students with average mathematical-logical intelligence can reach a better achievement than those with low one (4) In each category of mathematical-logical intelligence, TTW with RME approach and TPS with RME approach gave same mathematics achievement.
\end{abstract}

Keyword : Think Talk Write, Think Pair Share, Realistic Mathematics Education, Mathematical Logical Intelligence

\section{Introduction}

Education is an effort to develop the potential is owned by each. Education plays a role in improving human quality to realize the advanced and prosperous society. In the state of Indonesia, education aims to develop student's potentials to become human who have faith and be cautious, morals, skilled, creative, independent, and become citizens of democratic and responsible.

In formal education, mathematics is a lesson taught every level of school. The mathematics lessons play a role in developing logical, analytical, systematic, critical, 
and creative thinking skills. The mathematics lesson is expected to be understood by every student because it looked at mathematics as something useful for his life.

The importance of mathematics is not in line with the low mathematics achievement. The result of PAMER National Examination year 2015/2016 shows that national average score of mathematics in Junior High School level is considered the lowest score of other examined subjects, is only 50,24 percent. Compared with other subject matter, the subject of polyhedron a low result presentation, so that there are students difficulties in the subject. The mastery absorption of the national examination of junior high school in Karanganyar Regency with indicator solves the problem to skeleton concept in the amount 38,91 percent, the province level with the amount of 36,06 percent, and in national level with 46,04 percent. Also, mastery absorption with indicator area of polyhedron is obtained in the amount 37,64 percent in district level, 35,91 percent in province level, and 44,04 percent in national level [1]. Based on these data, it can be seen that the percentage of mastery absorption in the material of polyhedron in district level is lower than the percentage of national level.

The low mastery absorptive of national examination may be due to students being frightened by mathematics lessons, assume that mathematics unattractive, and difficult to understand. Students low success level in the mathematics has been a worry for a long time in my countries. There are a lot of factors affecting success in mathematics. One of these factors is students mathematics anxiety, in other words, their mathematical fear [2]. Fear of mathematics lessons causes students to be lazy to learn mathematics.

The low mastery absorptive of students is also influenced by many factors, both internal and external factors. One of the external factor might influence the low mastery absorptive is mathematics learning. In mathematics learning, many models can be used by teachers to improve mathematics achievement. Teachers need to apply a learning model that suitable the student's condition. When students find comfort in the learning process, the students will be faster in understanding the material provided by teachers, but in reality, there are still many teachers who use learning models that are not tailored to the student's condition. In the learning process, there are still many teachers who use direct learning model, where students tend to be passive listening to teacher explanations.

Based on the above information, need a way for student learning activities can be more optimal and improve mathematics achievement. One way to improve mathematics achievement is by applying cooperative learning model. The cooperative learning model is a student-centered learning model, and students are trained to be able and willing to work in small groups to achieve common goals so that learning is meaningful and students can understand the lessons material. Cooperative learning encourages students to discuss, debate, disagree, and ultimately to teach one another [3]. Therefore, cooperative learning model is expected to improve students' activeness in learning so that they can understand the lessons matter well.

Many type cooperative learning models that teachers can use in the learning process, such as Think Talk Write (TTW) model. The TTW pursuit model introduced by 
Huinker and Laughl basically has the stages of think, talk, and write. TTW model is a learning model that starts with think, the outcome of thinking is communicated by discussion, presentation, and then write the presentation results independently [4]. The activity of think, talk, and write is a mathematics learning activity that provides opportunities for students to participate actively in learning. Through the activities, students can develop language skills appropriately, especially conveying ideas in solving mathematical problems. Therefore, learning with TTW model is expected to encourage students to think and engage directly in the learning process.

In addition to the TTW model, there are other learning models can trigger students to play an active role in the learning process. The model is Think Pair Share (TPS). The basic foundation of Think Pair Share model is to make the students more active in the teaching-learning process by discussing with their classmates [5]. With TPS model students more active in the learning process, so it can give a positive influence on students in understanding the lesson. Think Pair Share is a cooperative learning technique which is said as a multi made discussion cycle in which students listen to a question or presentation, have time to think individually, talk with each other in pairs, and finally share responses with the large group [6]. The TPS learning model is a cooperative model that placing students in pairs to complete tasks through three stages: think, pair, and share. The learning model of TPS is expected to Encourage student activeness in the learning as well as give positive influence to the students' understanding.

To optimize mathematics achievement, an interesting approach is necessary to make students participate actively in the learning process by using reality knowledge students have already owned in their mind that is called Realistic Mathematics Education (RME) approach. An essential principle of RME is that engagement in mathematics for students should begin within a meaningful context. The development of understanding and the ability to make sense of mathematical representations begins with the student's informal reasoning [7]. RME approach appreciates mathematics with the realities students was known in their daily lives. RME approach guides students to gain meaningful knowledge so that students feel familiar with mathematics and generate interest and motivation in the mastery of the material. The philosophy underpinning Realistic Mathematics Education (RME) is that students should develop their mathematical understanding by working from the context that makes sense to them [8]. RME approach step according to Arends [9] was carried out through four stages, that is understanding contextual issues, solving contextual problems, comparing and discussing answers, and concluding. The learning model combined with the RME approach is expected to attract students 'attention and improve students' understanding of the lesson matter.

Learning model and learning approach that is used by teachers in class are not the only reasons that cause low mathematics achievement. There is another factor also influence their mathematics achievement, such as internal factors of students. Logical mathematical intelligence which consists of the ability to discover models, deductive 
reasoning, and logical thinking [10]. Mathematical-logical intelligence is the ability to reasoning or calculating logically, mathematically, seeing or recognizing patterns and analyzing abstract patterns, deductive-inductive and rational thinking. Components of mathematical-logical intelligence are the capacity to analyze problem logically, carry out the mathematical operation, and investigate issues scientifically [11]. Another opinion also suggests components of logical mathematical intelligence that are number/reasoning smart, analyze problem logically, and investigate issues scientifically [12]. Therefore, each student may have different mathematical-logical intelligence so that mathematics achievement also different.

This research aims to discover several matters as follows (1) which model is more effective to advance mathematics achievement between TTW using RME approach and TPS using RME approach, (2) which students will accomplish best mathematics achievement among students with high, average, and low mathematical-logical intelligence, (3) in each type of learning model, which students have better mathematics achievement between students who have mathematical-logical intelligence high, average, or low, (4) in each category of mathematical-logical intelligence, which have better mathematics achievement between students when taught using TTW model with RME approach or TPS model with RME approach.

\section{Research Method}

This research is a quasi experimental research with $2 \times 3$ factorial design. Valiabel independent for this research are TTW and TPS model with RME approach and mathematical-logical intelligence which divided into high, average, and low, while the dependent variable is the mathematics achievement in the subject of the polyhedron.

The population of this research was all students of the eight graders of junior high school in Karanganyar Regency in academic 2016/2017. The sample was taken by stratified cluster random sampling technique. The sample is SMPN 1 Tasikmadu, SMPN 2 Jaten, and SMPN 2 Gondangrejo. Grouping school was used data result of national examination is academic year 2015/2016 with three category, that is high, medium, and low category.

The data analysis in this study using two-ways analysis of variance with unequal cells. Before analysis of variance, prerequisite test first used normality test by Liliefors and homogeneity test by $\mathrm{F}$ test.

\section{Research and Discussion}

The result of this research used two-ways analysis of variance with unequal cells. Prerequisite test result concludes that all samples from the population have a normal distribution, have same various and have basic balance skills. The result of this research was as follows. 


\subsection{Normality Test}

Normality test used to find out whether the data of samples from normally distributed population. The result of normality test with significance level of $5 \%$ can be seen in table 1 below.

Table 1. The Result of Normality Test of Mathematics

\begin{tabular}{lrrl}
\multicolumn{4}{c}{ Achievement } \\
\multicolumn{1}{c}{ Group } & $\mathrm{L}_{\text {obs }}$ & $\mathrm{L}_{\text {table }}$ & \multicolumn{1}{c}{ Conclusion } \\
\hline TTW with RME & 0,0895 & 0,0739 & Normal \\
TPS with RME & 0,0913 & 0,0579 & Normal \\
High MLI & 0,1009 & 0,0945 & Normal \\
Average MLI & 0,0997 & 0,0873 & Normal \\
Low MLI & 0,1477 & 0,0783 & Normal \\
\hline
\end{tabular}

Based on the result in Table 1, see that $\mathrm{L}_{\mathrm{obs}}$ for each sample no more than $\mathrm{L}_{\text {table }}$. Therefore it can be concluded that the sample came from the normal-distributed population.

\subsection{HomogeinityTest}

Homogeneity test used to find out whether the data of population have the same variance or not. The result of homogeneity test with significance level of $5 \%$ can be seen in table 2 below.

Table 2. The Result of Homogeneity Test of Mathematics Achievement

\begin{tabular}{|c|c|c|c|c|}
\hline Group & K & $\chi^{2}$ obs & $\chi_{\text {tabel }}^{2}$ & Conclusion \\
\hline $\begin{array}{l}\text { Model with RME } \\
\text { approach }\end{array}$ & 2 & 4,4214 & 5,991 & $\begin{array}{c}\text { Population of } \\
\text { Homogeneity Variance }\end{array}$ \\
\hline $\begin{array}{l}\text { Mathematical- } \\
\text { logical intelligence }\end{array}$ & 3 & 5,3332 & 5,991 & $\begin{array}{c}\text { Population of } \\
\text { Homogeneity Variance }\end{array}$ \\
\hline
\end{tabular}

Based on the result in table 2, see that $\chi^{2}$ obs for each samples no more than $\chi^{2}$ table Thus the population has the similiar variance of homogenous.

\subsection{Analysis Test of Two Ways Analysis of Variance with Unequal Cells}

The result of two-ways analysis of variance test with significance level of 5\% can be seen in the table as follow. 
Table 3. Summary Analysis Test of Two Ways Analysis of Variance with Unequal Cells

\begin{tabular}{lcccccc}
\hline \multicolumn{1}{c}{ Source } & $\begin{array}{c}\text { Sum of } \\
\text { Squares }\end{array}$ & df & $\begin{array}{c}\text { Mean } \\
\text { square }\end{array}$ & $\mathrm{F}_{\text {obs }}$ & $\mathrm{F}_{\text {table }}$ & Decision Test \\
\hline $\begin{array}{l}\text { Learning Model } \\
\text { (A) }\end{array}$ & 619,8071 & 1 & 619,8071 & 5,3146 & 3,8919 & $\mathrm{H}_{0 \mathrm{~A}}$ Rejected \\
$\begin{array}{l}\text { Mathematical- } \\
\text { logical }\end{array}$ & 10471,2111 & 2 & 5235,6055 & 44,8929 & 3,0445 & $\mathrm{H}_{0 \mathrm{~B}}$ Rejected \\
$\begin{array}{l}\text { Intelligence (B) } \\
\text { Interaction (AB) }\end{array}$ & 1445,3735 & 2 & 722,6868 & 6,1967 & 3,0445 & $\mathrm{H}_{0 \mathrm{AB}}$ Rejected \\
$\begin{array}{l}\text { Error } \\
\text { Total }\end{array}$ & 21692,1361 & 186 & 116,6244 & & & \\
\hline
\end{tabular}

Table 4. The Marginal of Achievement Learning Mathematics

\begin{tabular}{lcccc}
\hline \multirow{2}{*}{ Learning Model } & \multicolumn{2}{c}{ Mathematical Logical Intelligence } & Marginal Average \\
& High & Average & Low & \\
\hline TTW with RME & 82,1905 & 70,3636 & 69,0435 & 75,1224 \\
TPS with RME & 82,7429 & 70,4348 & 56,6154 & 73,1064 \\
Marginal & 82,4416 & 70,4051 & 64,5556 & \\
Average & & & & \\
\hline
\end{tabular}

Based on the result in table 3, see that $\mathrm{F}_{\mathrm{A}}=5,3146>\mathrm{F}_{0,05 ; 1 ; 186}=3,8919$, in this case means $\mathrm{H}_{0 \mathrm{~A}}$ be Rejected. It means that there are different mathematics achievement between students which applied TTW model with RME approach and TPS model with RME approach. So, we can reach conclusion that mathematics achievement of students who applied TTW model with RME approach is better than students which applied TPS model with RME. This is because in the TTW model there is the process to write individually after understanding the lesson matter at the stage talk/discussion. Writing is seen as the way for individuals to reflect on or explain in detail certain mathematical ideals [13].

For $\mathrm{F}_{\mathrm{B}}=44,8929>\mathrm{F}_{0,05 ; 2 ; 186}=3,0445$, in this case $\mathrm{H}_{0 \mathrm{~B}}$ be Rejected. It means that there are different mathematics achievement between students who have mathematical logical intelligence high, average, and low. For $\mathrm{F}_{\mathrm{AB}}=6,1967>\mathrm{F}_{0,05 ; 2 ; 186}=3,0445$, in this case $\mathrm{H}_{0 \mathrm{AB}}$ be Rejected. Therefore, an interaction between learning model and students' mathematical-logical intelligence is identified.

Because of $\mathrm{H}_{0 \mathrm{~B}}$ be Rejected, Whereas there are three values for the mathematicallogical intelligence variable, it is necessary to post analusis of variance test to see which level of mathematical-logical intelligence which gives different effect by using double comparison test between rows. The result of summary of double comparison between lines as follows. 
Table 5.The Summary of Double Comparison Between

\begin{tabular}{clll}
\multicolumn{4}{c}{ rows } \\
\hline $\mathrm{H}_{0}$ & $\mathrm{~F}_{\text {obs }}$ & $2 \mathrm{~F}_{0,05 ; 2 ; 192}$ & Decision Test \\
\hline$\mu_{1 .}=\mu_{2 .}$ & 48,4400 & 6,0859 & $\mathrm{H}_{0}$ Rejected \\
$\mu_{2 .}=\mu_{3 .}$ & 67,2902 & 6,0859 & $\mathrm{H}_{0}$ Rejected \\
$\mu_{1 .}=\mu_{3 .}$ & 7,2557 & 6,0859 & $\mathrm{H}_{0}$ Rejected \\
\hline
\end{tabular}

Based on table 5, see that third $\mathrm{H}_{0}$ rejected. Therefore, it can be concluded that each level of different mathematical-logical intelligence variables gives different effects, so students with high mathematical-logical intelligence can reach a better mathematics achievement than those with average and low, whereas students with average mathematical-logical intelligence can reach a better achievement than those with the low one. One of the internal factors that affect mathematics achievement that is mathematical-logical intelligence. People using mathematical-logical intelligence are skilled in inductive/deductive reasoning and logic, and exhibit great strength to solve problems. Their ability to make connections between pieces of information is outstanding [14]. Students with mathematical-logical intelligence will be skilled in thinking inductive and deductive, have the ability to solve problems and not give up when faced with a difficult problem.

In addition, since $\mathrm{H}_{0 \mathrm{AB}}$ is also rejected, it is necessary to look at the average comparisons between cells on rows or the same column. The result of double comparison between cells as follows.

Table 6.Summary of Double Comparison Between Cells on The Same

\begin{tabular}{cccc}
\multicolumn{4}{c}{ Column } \\
\hline $\mathrm{H}_{0}$ & $\mathrm{~F}_{\mathrm{obs}}$ & $5 \mathrm{~F}_{0,05 ; 5 ; 192}$ & Decision Test \\
\hline$\mu_{11}=\mu_{12}$ & 22,1641 & 11,3057 & $\mathrm{H}_{0}$ Rejected \\
$\mu_{11}=\mu_{13}$ & 22,0256 & 11,3057 & $\mathrm{H}_{0}$ Rejected \\
$\mu_{12}=\mu_{13}$ & 0,2025 & 11,3057 & $\mathrm{H}_{0}$ Accepted \\
$\mu_{21}=\mu_{22}$ & 25,8185 & 11,3057 & $\mathrm{H}_{0}$ Rejected \\
$\mu_{21}=\mu_{23}$ & 55,4850 & 11,3057 & $\mathrm{H}_{0}$ Rejected \\
$\mu_{22}=\mu_{23}$ & 16,5973 & 11,3057 & $\mathrm{H}_{0}$ Rejected \\
\hline
\end{tabular}

Table 7. Summary of Double Comparison Between Cells on The Same Rows

\begin{tabular}{cccc}
\hline $\mathrm{H}_{0}$ & $\mathrm{~F}_{\mathrm{obs}}$ & $5 \mathrm{~F}_{0,05 ; 5 ; 192}$ & Decision Test \\
\hline$\mu_{11}=\mu_{21}$ & 0,0499 & 11,3057 & $\mathrm{H}_{0}$ Accepted \\
$\mu_{12}=\mu_{22}$ & 0,0008 & 11,3057 & $\mathrm{H}_{0}$ Accepted \\
$\mu_{13}=\mu_{23}$ & 10,999 & 11,3057 & $\mathrm{H}_{0}$ Accepted \\
\hline
\end{tabular}

Based on table 6, concluded that in TTW model with RME approach, students with high mathematical-logical intelligence can reach a better mathematics achievement than those with average and low, whereas students with average and low mathematical- 
logical intelligence have the same mathematics achievement. Students with high mathematical-logical intelligence are easier to understand a lesson material than students with average and low mathematical-logical intelligence, whereas students with average mathematical-logical intelligence may not understand the material well at the time of the discussion so that the write stage can not conclude the lesson matter as well as with students with low mathematical-logical intelligence. Both writing and discussion are seen as integral parts of communication that promote the deeper understanding of concept [13]. This shows that between stage talk and write is a series of stages that can support students in understanding the concept, if students are less understanding at stage talk then the students will have difficulty in writing conclusions about the material being studied. Therefore, students with average and low mathematical-logical intelligence have similar achievements may be due to their lack of understanding at stage talk resulting in difficulty at the stage write.

In TPS model with RME approach students with high mathematical-logical intelligence can reach a better mathematics achievement than those with average and low, whereas students with average mathematical-logical intelligence can reach a better achievement than those with the low one. This is because students with high mathematical-logical intelligence will be easy to find solutions to the problems was given. For students with average mathematical logical intelligence, they will work on the problem and give up if they can not solve it if they find obstacles in solving the problem. In addition, students who have low mathematical-logical intelligence have a quick behavior of giving up when working on the difficult problem. They also have difficulty in understanding new material and weak in calculate or matters relating to reasoning and think logically.

Based on table 7, concluded that in each category of mathematical-logical intelligence, TTW with RME approach gave same mathematics achievement with TPS with RME approach. Students who have high mathematical-logical intelligence not give up on problem-solving and not depend on their friends. In addition, students with the high mathematical-logical intelligence more easily understand lesson material than students with average and low mathematical-logical intelligence. If students with average mathematical-logical intelligence find obstacles in solving the problem, then they easily give up. On the other hand, students with low mathematical logical intelligence also have difficulty in understanding new materials and weak in calculating or matters relating to reasoning and think logically. Therefore, the characteristics of each level of mathematical logical mathematical causes students wich applied TTW model with RME approach or TPS model with the RME gave same mathematics achievement.

\section{Conclusion}

Based on the explanation on result and discussion, it can be concluded that TTW with RME approach gave better mathematics achievement than TPS with RME approach, students with high mathematical-logical intelligence can reach a better mathematics achievement than those with average and low, whereas students with average 
mathematical-logical intelligence can reach a better achievement than those with low one, in TTW model with RME approach, students with high mathematical-logical intelligence can reach a better mathematics achievement than those with average and low, whereas students with average and low mathematical-logical intelligence have the same mathematics achievement, whereas in TPS model with RME approach students with high mathematical-logical intelligence can reach a better mathematics achievement than those with average and low, whereas students with average mathematical-logical intelligence can reach a better achievement than those with low one, in each category of mathematical-logical intelligence, TTW with RME approach gave same mathematics achievement than TPS with RME approach.

\section{Acknowledgements}

Authors wishing to Allah SWT, whom with his willing giving the opportunity to complete this research, to parents for giving support and also staff ofPost Graduate of Mathematics Education, Sebelas Maret University for providing the necessary facilities for the preparation of the research.

\section{References}

[1] Ministry of Education and Culture 2015 National Education Standards Agency

[2] Peker M 2008 Eurasia Jornal of Mathematics, Science \& Technology Education 4 22

[3] Huang C Y Proc. Nati. Sci, Counc. ROC (C) 10256

[4] Hariyati R et al 2013 Unnes Journal of Mathematics Education Research 23

[5] Sugiarto D and Sumarsono P 2014 International Journal of English and Education 3207

[6] Azlina 2008 Collaborative Teaching Environment System Using Think Pair Share Technique Retrieved (dscape.fsktm.um.edu.my)

[7] Webb D C et al 2011 Journal of Mathematics education at Teacher College 24

[8] Dickinson P and Hough S 2012 Center for Mathematics Education (hoddereducation.co.uk)

[9] Yuharsiti 2012 Jurnal Peluang 182

[10] Sharifi H P 2008 Jornal of Educational Innovations 2412

[11] Abdulkarim R and Aljadiry A 2012 Europen Journal of Social Science 273

[12] Fetaji B and Fetaji M 2009 Electronic Journal of e-Learning 75

[13] Kosko K W and Wilkins J L M 2010 International Electronic Journal of Mathematics Education 580

[14] Marefat 2007 Pazhuhesh-e Zabanha-ye Kharehi 32146 